\title{
Correspondence
}

\section{Insect Mortality}

SrR,--I wish to direct the attention of biologists to the dangers of unintentional insecticidal contamination in laboratories. We recently had a new laboratory built in order to investigate, on behalf of the World Health Organization, the behaviour of Anopheles gambiae. This project necessitated rearing larvae of this mosquito in bowls of water in the new laboratory at a temperature of about $27^{\circ} \mathrm{C}$. Very few of the eggs of A. gambiae hatched, however, and all the larvae from the few that did died within one or two days. Further, larvae reared to a late stage of development outside the laboratory, and also healthy adults, dicd within a very short time after being placed in this laboratory. It took us some time to discover that the decorators had used a paint on the ceiling which contained $\gamma$-BHC, an insecticide well known for its fumigant effect. Then, after further setbacks, we found that the actual ceiling and insulation board covering the interior walls had been sealed before it left the suppliers with paint containing organochlorine insecticides. Our only remedy now is to remove completely all contaminated board and redecorate with material that our chemists have tested and shown to be free from insecticides.

I have since learnt that this type of insecticidal contamination has occurred in several laboratories in Britain, resulting in damage to insect colonies. What may well be of even greater danger is that such contamination in laboratories may go undetected, and yet its presence affect the results of laboratory investigations.

Yours faithfully, M. W. Service

The Nature Conservancy,

Monks Wood Experimental Station,

Abbots Ripton, Huntingdon.

$D N A \rightleftharpoons R N A$

SIR,- - The interesting reports by D. Baltimore, as well as H. Temin and S. Mizutani (Nature, 226, 1209; 1970), in which the authors show that a natural RNA can serve as a template for DNA synthosis, are similar to the report of Lee-Huang and myself, showing that the helical RNA polynucleotide, poly $(A+U)$, can serve as a template for the synthesis of the DNA polymer poly $(\mathrm{dA}+\mathrm{T}$ ) (Proc. US Nat. Acad. Sci., 50, 1116; 1963). Though our system employs $E$. coli DNA polymerase while theirs uses viral DNA polymerase, it seems most likely that the basic mechanism for information transfer from RNA to DNA is the same for the two cases. The fact that such transfor can occur should be considered not only in the case of viruses, but in general when one is dealing with the problems of DNA and RNA biosynthesis.

Yours faithfully, Liebe F. Cavatieri

Sloan-Kettoring Institute for Cancer Research, New York, New York 10021.

\section{Continental Drift}

Sir,--Ireland and Britain may have their problems, but I was surprised that they had drifted so far apart that the leading British scientific journal should consider Ireland "Scandinavian" (Nature, editorial, July 4).

Yours faithfully,

Trevor C. Weekes

Smithsonian Institution,

Mt Hopkins Observatory,

PO Box 97,

Amado, Arizona 85640, USA.

\section{Misuses for Fructose}

SIR,--One of your correspondents has reported (Nature, 226, 1006; 1970) that the clinical value of fructose emerged clearly at a recent symposium held at the Royal Society of Medicine under the auspices of two commercial firms. An important problem, that apparently was neglected at the meeting, was the potential toxicity of fructose (sometimes called "lacvulose"). Mäenpää et al. ${ }^{1}$ have indeed observed that an infusion of fructose causes a drastic reduction in the concentration of ATP and of inorganic phosphate in the liver together with a depression of protein synthesis and an overproduction of uric acid. This is interpreted as the result of a rapid deposition of fructose 1-phosphate at a concentration that exceeds the normal level of inorganic phosphate in the liver ${ }^{2-4}$. In this laboratory, a concentration of fructose 1-phosphate as high as $10 \mathrm{mM}$ has been observed two minutes after the intravenous administration of fructose to mice. As phosphate is not driven into the liver at such a rapid rate ${ }^{1}$, one can assume that AMP, instead of being phosphorylated, is deaminated and catabolized to uric acid.

It is not clear at present if these striking events explain the painful abdominal sensation that many subjects feel after an intravenous load of fructose. The possible relationship between the presence of fructose in the diet and the pathogenesis of gout needs to be clarified.

I am also curious to know what enzyme, attached to solid polymer reactors, will cheaply convert starch into fructose.

Yours faithfully, H. G. Hers

Laboratoire de Chimie Physiologique,

Université de Louvairn,

Louvain, Belgium.

${ }^{1}$ Mäenpää, P. H., Raivio, K. O., and Kekomäki, M. P., Science, 161, 1253 (1968).

${ }^{2}$ Günther, M., Sillero, A., and Sols, A., Enz. Biol, Clin., 8, 341 (1967).

s Heinz, F., and Junghänel, J., Hoppe-Seyler's Z. Physiol. Chem., 350, 859 (1969).

${ }_{4}$ Burch, H. B., Lowry, O. H., Meinhardt, L., Max, P., and Chyu, K., J. Biol. Chem., 245, 2092 (1970). 